\title{
Traditionally managed patch of Cladonia-Scots pine forest in the Biebrza valley - specifity of the protected forest community shaped by human activity
}

\author{
"Piotr T. Zaniewski, " Adam Bernatowicz, ${ }^{* * *}$ Lukasz Kozub, ${ }^{* * * *}$ Ewa Truszkowska, \\ ${ }^{* * * *}$ Iwona Dembicz, ${ }^{* * * * *}$ Malgorzata Wierzbicka
}

\author{
*Department of Forest Botany, Faculty of Forestry, Warsaw University of Life Sciences, \\ Nowoursynowska 159,02-776 Warsaw, Poland, e-mail: piotr.zaniewski@wl.sggw.pl \\ ${ }^{* *}$ Department of Monitoring and Scientific Research, Biebrza National Park, Osowiec-Twierdza 8, \\ 19-110 Goniądz, Poland \\ *** Department of Plant Ecology and Nature Protection, Institute of Botany, Faculty of Biology, University of Warsaw, \\ Aleje Ujazdowskie 4, 00-0478 Warszawa, Poland \\ ${ }^{* * * *}$ Regional Environmental Center, Poland, Grójecka 22/24 room 36, 02-301 Warszawa, Poland \\ ${ }^{* * * * *}$ Laboratory of Ecotoxicology, Institute of Botany, Faculty of Biology, University of Warsaw, \\ Miecznikowa 1, 02-096 Warszawa, Poland
}

\begin{abstract}
The path of Cladonia-Scots pine forest located on dune in Biebrza valley (NE Poland) was carefully studied in order to assess the influence of recently obsolescent selection cutting management on terrestrial lichen biota. Transect was located along the dune ridge crossing both lichen rich pine forests and other adjacent communities. Distinctive habitat patches were characterized by relevé. Within the relevé area measurements of cutting intensity and soil properties were carried out and soil samples were collected for laboratory analyses. It was found, that subsoil properties are rather similar on the whole dune, which indicates the main influence of management intensity on plant communities studied. All known development stages of Cladonio-Pinetum were observed. The characteristic lichen species preferred low organic horizon depth and low canopy closure. These factors are positively correlated with cutting intensity. The studied path was compared with other described patches of Cladonia-Scots pine in Poland and additional proposals of practices urgently needed to conserve these endangered habitat were given. In spite of already practiced slash removal, there are litter raking and complete cessation of clearcuts in favour of the selection cutting management are necessary for Cladonia-Scots pine forest conservation.
\end{abstract}

Key words: Cladonio-Pinetum, Cladonia stellaris, habitat conservation, lichens, organic layer, Natura 2000, selection cutting.

\section{Introduction}

Among all Pinus sylvestris dominated forests, lichen-rich pine forest (Cladonio-Pinetum Juraszek 1927) occupies the most dry and nutrient poor locations (Matuszkiewicz 2005). That forest type is characterised by scarcity of vascular plants in the undergrowth and well developed lichen and moss layer. Its range includes Central and East-Cen- tral Europe. The territory of Poland lies in the centre of its distribution (Kelly \& Connoly 2000; Solon 2003). Within the whole range lichen-rich pine forest is a rare and endangered community (Celiński et al. 1997; Van Tol et al. 1998; Prieditis 2002; Danielewicz \& Pawlaczyk 2004; Zaniewski et al. 2012). Due to the role which in Central Europe the above community plays as a habitat for many terrestrial lichens (mainly Cladonia spp.), lichen-rich pine forests are 


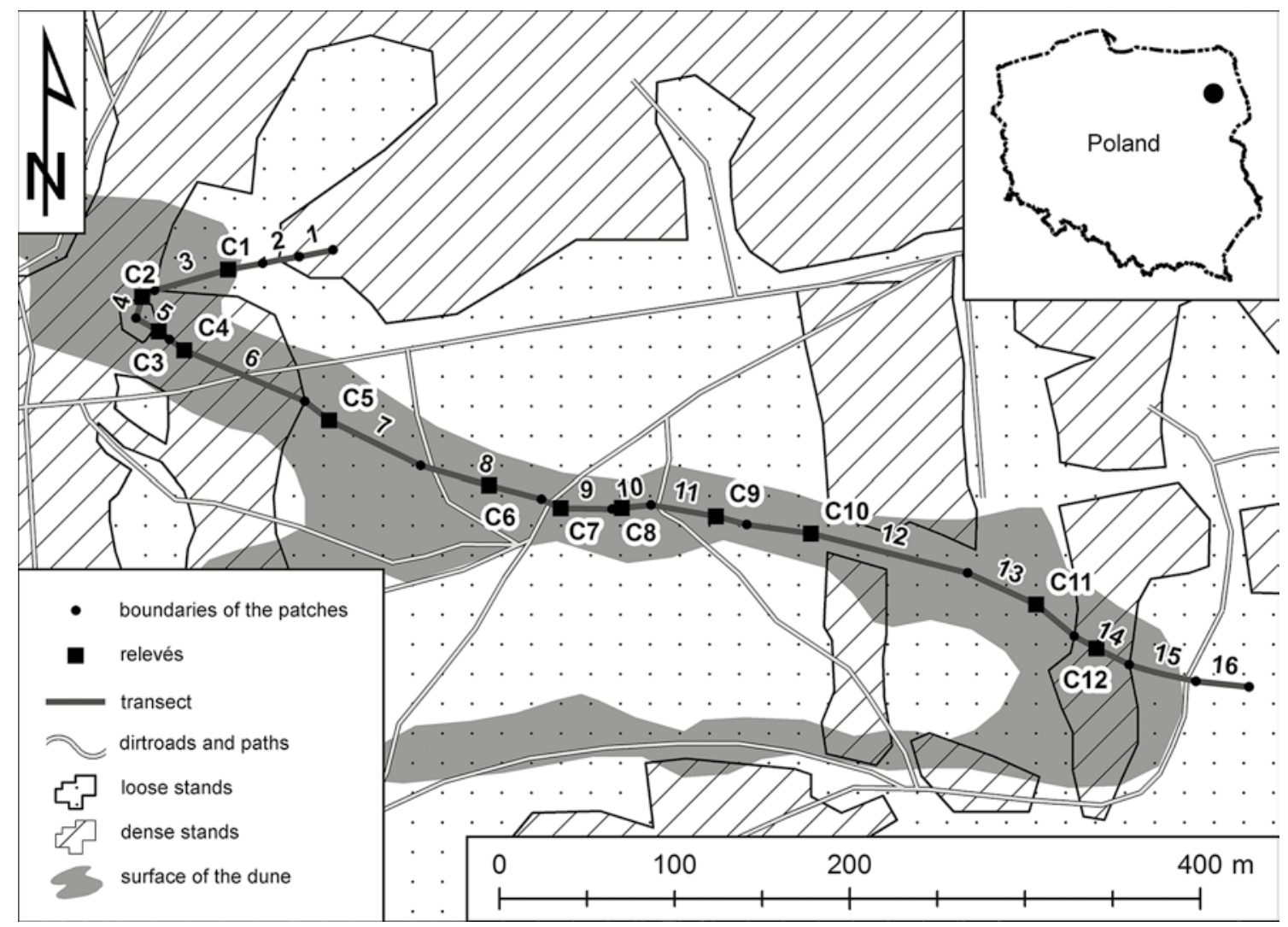

Figure 1 Location of transect in the research area

protected under community law as a Natura 2000 habitat type 91T0 (Council Directive 92/43/EEC). Despite recent improvements (Matuszkiewicz 2008) the knowledge on Cladonia-rich pine forests still desires urgent completion. Due to the changes in forestry practice over the last century (Magnuski 1997; Zerbe 2002), little is known about the traditional, extensive use of pine forests.

During the summer of 2012 in the vicinity of Stójka village (Trzcianne community), a new well preserved patch of the lichen-rich pine forest (Cladonio-Pinetum) was discovered. Due to the visible traditional management of the above patch a detailed study was carried to assess the influence of selection cutting management on the distribution of lichens characteristic for lichen-rich pine forests.

\section{Materials and methods}

The study area is located within the Biebrza Basin (Kondracki 2009), around $200 \mathrm{~m}$ outside the borders of the Biebrza National Park, but within its outer protection zone. The locality is a mosaic of dunes and peatlands at the edge of the Lower Biebrza Basin around $2 \mathrm{~km}$ west from the slope of Białystok Upland. In 1865 the study area was the forest edge (Reymann 1865). During early $20^{\text {th }}$ century (Karte... 1915; Mapa taktyczna... 1930) that area was covered by forest. Settlements of the Stójka village located nowadays around $600 \mathrm{~m}$ from the study site were documented already in 1930 and single settlements located circa $1.5 \mathrm{~km}$ east from the site were existing already in 1915 (Karte... 1915; Mapa taktyczna... 1930).

Fieldwork was conducted in July and September 2012. The study was carried by transect method (Faliński 1990). Transect was located along the ridge of the dune (Fig. 1). All distinctive habitat patches were descriptively characterized. A series of releves $\left(150 \mathrm{~m}^{2}\right)$ using modified 9-degree Braun-Blanquet's (1928) sampling scale (Barkmann et al. 1964) was performed. Measurements of the thickness of the organic horizon and the top mineral soil horizon were carried out. Samples of soil were collected from the top mineral soil horizon in order to determine $\mathrm{pH}$, electrolytic conductivity $\left(\mathrm{H}_{2} \mathrm{O}, 10: 50\right)$ and organic matter content (based on loss at ignition). Additionally a sieve analysis was performed (according to norm BN-78/9180-11). Within the area of each relevé the number of stumps left after felled trees was counted, in order to estimate the severity of selection cutting management. The fit Gaussian model analysis was carried out, using MicroCal Origin software 


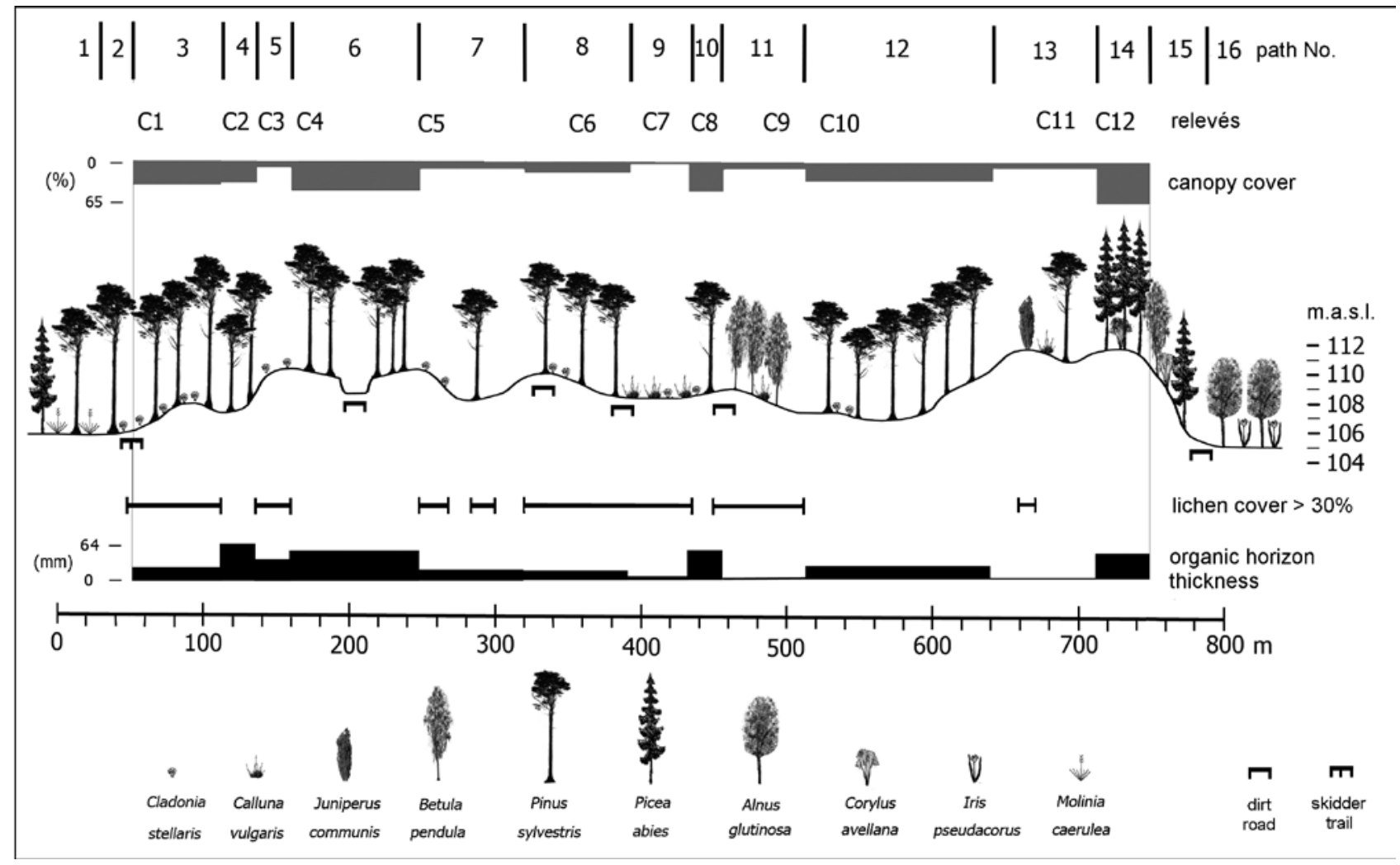

Figure 2. Characteristics of land use along the transect near the village of Stójka

(MicroCal Software Inc., USA) in order to check relations between collective lichen cover sensu Tüxen \& Ellenberg (1937) and recorded variables.

\section{Results}

Within the transect following the ends and the top of the dune, a series of 12 relevés $(\mathrm{C} 1-\mathrm{C} 12)$ was taken and 16 sections with uniform land use and habitat conditions were distinguished (Fig. 2). Their characteristics are shown below (birch - Betula pendula, hazel - Corylus avellana, pine - Pinus sylvestris, spruce - Picea abies, heather Calluna vulgaris, in parentheses - the length of the patches on the transect):

1. moist coniferous forest (Molinio-Pinetum), dense high polewood, with pine and spruce $(>30 \mathrm{~m})$,

2. mesic pine forest (Dicrano-Pinion), dense high polewood, with moss and dwarf shrub undergrowth, $(21 \mathrm{~m})$,

3. lichen-rich pine forest (Cladonio-Pinetum), relatively loose stand (high polewood) with visible selection cutting management and high lichen cover including $\mathrm{Cla}$ donia stellaris $(\mathrm{C} 1,64 \mathrm{~m})$,

4. moss dominated pine forest (Dicrano-Pinion) within lowering of dune (high polewood), the forest floor dominated by Pleurozium schreberi, almost without selection cutting, (C2, $21 \mathrm{~m})$,

5. "gap" in the dense pine high polewood, resembling lichen-rich pine forest (Cladonio-Pinetum), with the dominance of Cladonia rangiferina and $\mathrm{Cl}$. stellaris (C3, $23 \mathrm{~m})$,

6. moss dominated pine forest, dense high polewood, with no signs of selection cutting and small share of lichens (C4, $85 \mathrm{~m})$,

7. loose lichen-rich pine forest (Cladonio-Pinetum) with very intense selection cutting (only single trees left), with abundant natural regeneration of pine, high lichen cover (Cladonia arbuscula, Cl. rangiferina, Cl. stellaris - the latter species with visible necrotic changes, probably caused by rapid overexposure of undergrowth as a result of logging), (C5, $76 \mathrm{~m})$,

8. lichen-rich pine small polewood (Cladonio-Pinetum), single tree felling present, with a high cover of lichens (C6, $71 \mathrm{~m})$,

9. heath (Calluno-Arctostaphylion) with natural regeneration of birch and pine, additionally some spruce trees planted, high lichen cover, including $\mathrm{Cl}$. stellaris, (C7, $41 \mathrm{~m})$,

10. mossy pine high polewood (Dicrano-Pinion), (C8, $22 \mathrm{~m})$, 
Table 1. Characteristics of the patches distinguished on the transect

\begin{tabular}{|c|c|c|c|c|c|c|c|c|c|c|c|c|}
\hline Sample no. & $\mathrm{C} 11$ & C9 & $\mathrm{C} 7$ & C6 & C5 & $\mathrm{C} 10$ & $\mathrm{C} 1$ & $\mathrm{C} 3$ & $\mathrm{C} 8$ & $\mathrm{C} 4$ & $\mathrm{C} 2$ & $\mathrm{C} 12$ \\
\hline organic horizon thickness (mm) & 0 & 1 & 3 & 16 & 16 & 21 & 23 & 33 & 48 & 51 & 64 & 41 \\
\hline number of stumps (pieces) & 0 & 3 & 4 & 4 & 6 & 2 & 1 & 0 & 4 & 0 & 1 & 0 \\
\hline a - tree layer cover $(\%)$ & 5 & 10 & 0 & 15 & 10 & 30 & 40 & 10 & 50 & 50 & 35 & 65 \\
\hline b - shrub layer cover $(\%)$ & 0 & 1 & 1 & 0 & 2 & 0 & 1 & 0 & 0 & 0 & 1 & 10 \\
\hline $\mathrm{c}$ - herb layer cover $(\%)$ & 30 & 20 & 55 & 10 & 15 & 20 & 8 & 30 & 5 & 5 & 20 & 20 \\
\hline d - cryptogam layer cover $(\%)$ & 25 & 70 & 60 & 80 & 50 & 90 & 60 & 90 & 95 & 95 & 95 & 50 \\
\hline lichen cover $(\%)$ & 20 & 60 & 40 & 50 & 45 & 15 & 50 & 40 & 5 & 1 & 1 & 0 \\
\hline moss cover $(\%)$ & 5 & 10 & 20 & 30 & 5 & 75 & 10 & 50 & 90 & 95 & 95 & 50 \\
\hline bare soil (\%) & 40 & 15 & 5 & 0 & 5 & 0 & 0 & 0 & 0 & 0 & 0 & 0 \\
\hline litterfall cover $(\%)$ & 20 & 25 & 10 & 40 & 35 & 40 & 50 & 5 & 30 & 35 & 50 & 75 \\
\hline a1 Betula pendula & & & & & & & & & & & & $2 \mathrm{a}$ \\
\hline a1 Picea abies & & & & & & & & & & & & $2 \mathrm{~b}$ \\
\hline a1 Pinus sylvestris & & & & $2 \mathrm{a}$ & & & & & 3 & 3 & 3 & \\
\hline a2 Betula pendula & & $2 \mathrm{a}$ & & & & & & & & & & $2 \mathrm{a}$ \\
\hline a2 Picea abies & & & & & & & & & & & & 3 \\
\hline a2 Pinus sylvestris & 1 & & & & $2 \mathrm{a}$ & 3 & 3 & $2 \mathrm{a}$ & $2 \mathrm{~b}$ & $2 \mathrm{~b}$ & & \\
\hline $\mathrm{b}$ - trees and shrubs in shrub layer & 0 & 0.5 & 2.5 & 0 & 2.5 & 0 & 0.5 & 0 & 0 & 0 & 0.5 & 8 \\
\hline$c-$ trees and shrubs in herb layer & 1 & 2.5 & 4.5 & 5.5 & 11.75 & 5.5 & 3.5 & 1.5 & 1.5 & 5 & 4 & 2.5 \\
\hline Koelerio-Corynephoretea & 15.75 & 51.75 & 5.1 & 2.1 & 4.1 & 2.5 & 0.6 & 0 & 1.0 & 2.5 & 0.5 & 0.5 \\
\hline Nardo-Callunetea & 22.75 & 22.75 & 67.5 & 2.0 & 4.0 & 10.25 & 3.5 & 8.75 & 1.0 & 0 & 9.75 & 0.5 \\
\hline Cladonio-Pinetum & 3 & 6.5 & 16.75 & 43.0 & 30.5 & 15.75 & 45 & 37.5 & 3 & 1 & 1 & 0 \\
\hline Vaccinio-Piceetea & 3 & 3 & 21 & 37 & 3.6 & 72.5 & 14.75 & 57.75 & 84.75 & 97.75 & 96 & 69.5 \\
\hline other species & 1 & 4 & 4.6 & 1 & 0.5 & 0.5 & 1 & 0.5 & 1 & 0 & 0.1 & 2.5 \\
\hline
\end{tabular}

11. fairly young birch plantation (Dicrano-Pinion) with high cover of heather, lichen rich $(\mathrm{C} 9,56 \mathrm{~m})$,

12. loose pine forest (with uneven tree age of small and high polewood stages), with domination of heather and lichens, including $\mathrm{Cl}$. stellaris $(\mathrm{C} 10,129 \mathrm{~m})$,

13. very loose pine stand (Dicrano-Pinion) after intense logging, patches of exposed soil and dry sandy grassland vegetation (Spergulo-Corynephoretum), presence of heather, juniper (Juniperus communis) and lichens (C11, $71 \mathrm{~m})$,

14. dense spruce plantation (Vaccinio-Piceetea), with undergrowth of hazel, large shading reduces the growth of lichens, accelerate the accumulation of litterfall on the forest floor and promotes Hylocomium spendens, a humicolous and hygrophilous moss (C12, $35 \mathrm{~m})$,

15. mixed forest (Querco roboris-Pinetum) with birch, hazel and spruce, undergrowth dominated by grasses and bilberry (Vaccinium myrtillus), lily of the valley (Convallaria majalis), (of high polewood age) (40 m),
16. alder carr (Ribeso nigri-Alnetum) dominated by young alder trees with a high cover of sedges and Iris pseudoacorus, (of small polewood age) $(>20 \mathrm{~m})$.

Results of soil analysis showed rather little variation between samples. Shares of particular fractions were: for coarse sand $1.6 \%$ (SD $0.8 \%$ ), for medium sand $17.5 \%$ (SD $5.2 \%$ ), for fine sand $75.5 \%$ (SD 5.6\%) and for very fine sand, silt and clay in total 5.3\% (SD 0.9\%). The $\mathrm{pH}$ values varied between 4.05 and 4.58. Variation of electrolytic conductivity was a bit larger and comprised between 30.1 and $104 \mu \mathrm{S} \cdot \mathrm{cm}^{-1}$. The presence of wood charcoal was recorded in all 12 soil samples. More differences between samples were noted for the intensity of selection cutting (0-6 stumps), the thickness of the organic horizon $(0-64 \mathrm{~mm})$ and organic matter content in the top mineral soil horizon (1.0-2.7\%). Somewhat less variable was the thickness of the top mineral soil horizon (38-97 mm).

Samples in Table 1 were arranged in accordance with rising thickness of the organic horizon and with the increasing tree layer cover. Participation of species from individual syntaxa was presented as collective cover. At 


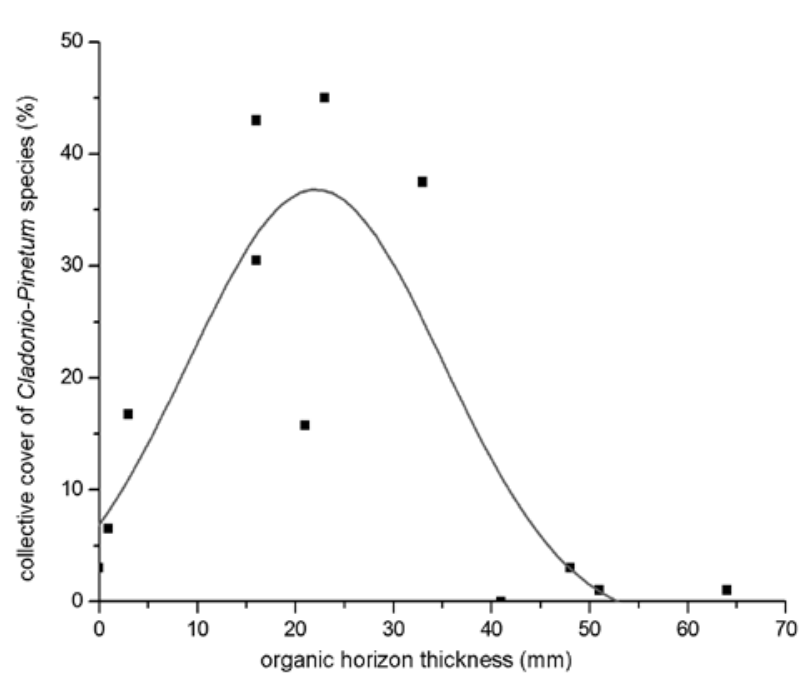

Figure 3. Relation between collective cover of Cladonio-Pinetum characteristic lichen species and organic horizon thickness within lichen-rich pine forest located on dune near Stójka village - the Gaussian fit $\left(\mathrm{R}^{2}=0.71\right)$

the lowest values of tree cover and thickness of organic horizon a high cover of dry sandy grassland species (Koelerio-Corynephoretea) was visible. With increasing values of abovementioned variables the latter species with drawn and the temporary increase of cover of species connected to Nardus grasslands and heaths (Nardo-Callunetea) could be observed. Then with increasing values of tree cover and organic horizon thickness a growing importance of lichens connected to lichen-rich pine forest (Cladonio-Pinetum) is visible, which in turn give way to generalist coniferous forest species (Vaccinio-Piceetea). The maximum cover of the typical forest lichens was observed at the organic horizon thickness ranging between 16 and $33 \mathrm{~mm}$ and the tree layer cover from 10 to $40 \%$. The Gaussian fit of collective cover of lichens to organic horizon thickness was high $\left(\mathrm{R}^{2}=0.71\right)$ with the maximum on $22.1 \mathrm{~mm}$ depth (Fig. 3) and in relation to tree layer cover was medium $\left(\mathrm{R}^{2}=0.34\right)$ with the maximum at $18 \%$.

\section{Discussion}

The results of carried soil analyses suggest that the primary character of the substrate was not the main factor influencing the diversity of communities within the 12 major divisions of the transect (where relevés were performed). The presented study indicates much more significant impact of a character and intensity of human activity on the development of forest communities within the studied area. Presence of such disturbance as selection cutting or clearcuts is often associated with lichen-rich pine forest stands (Juraszek 1927; Kobendza 1930). The presence of such management in the study area and its surrounding has been observed nowadays and also recorded on a map from 1865 , where the study site was located on the edge of deforested area. Analysis of the historical maps suggests long continuity of many forest microhabitats on the dune, even when slightly changing locations (landscape continuity), and in the broader scale, including dune surroundings, the continuity of forest cover in some particular spots of the area (stand continuity). Both abovementioned facts implicate that the area of research is characterized by ecological continuity of forest communities (Nordén \& Appelqvist 2001).

Forest communities on inland dunes are the subject of succession, which was visible also within presented site. They start from the heliophilous forms (Juraszek 1927; Zielińska 1967; Cieśliński 1979) of Cladonio-Pinetum (C11, C9) rich in grassland species from Koelerio-Corynephoretea class, than through slight increase of heath and Nardus-grassland species (C7) from Nardo-Callunetea class to well-developed stages of Cladonio-Pinetum forest (C6, C5, $\mathrm{C} 3, \mathrm{C} 1$ ) which further transform into moss dominated stages of mesic pine forests $(\mathrm{C} 12, \mathrm{C} 8, \mathrm{C} 4, \mathrm{C} 2)$. This process is consistent with observations by Zielińska (1967) and Faliński et al. (1993). Within the research site the straightforward successional path is however, within some patches, reverted by extensive selection cutting.

The low thickness of organic horizon and low tree canopy cover positively affected the occurrence of forest lichen species in the study area. This result is consistent with the results by Zaniewski et al. (2012), that Cladonio-Pinetum connected lichen species favour lower values of the mentioned variables. Low cover of the canopy layer was the most important factor promoting lichen diversity in pine forests of Borská Nižina Lowland (SW Slovakia) and Bory Tucholskie (Dingová Košuthová et al. 2013). However in the present study this variable seems to be less important for the lichen cover than organic horizon thickness. There were no traces of present litter raking in the study site, however one cannot exclude the application of this procedure in the past. Nowadays organic horizon might be damaged and soil might be exposed on the site as a result of frequent single tree cutting which maintained whole web of dirt roads and skidder trail within the study area (Fig. 2). Soil damages are a regular part accompanying timber harvest in pine forests (Suwała 2004). It seems therefore that the unordered forest management resulting in disturbance of organic and the top mineral soil horizons as well as low canopy cover, continuing for a long time period, is the most important factor enabling the persistence of lichen-rich pine forests within the study site. Our results support thus the recommendations of Węgrzyn \& Masłowska (2010) to remove the whole timber after thinning procedures in order to protect lichen-rich pine forest 
patches. Moreover, the obtained results indicate the particular importance of litter removal in lichen-rich pine forest maintenance and restoration. Thus such procedures as litter racking should be considered as a tool of abovementioned habitat type management and restoration. The effect of described practices is to remove the excess of nutrients from the particular patch (Kreutzer 1979) and decrease their amounts in the soil as well as decrease the humidity of ground layer (Dzwonko \& Gawroński 2002; Prietzel $\&$ Kaiser 2005). Such actions facilitate the development of lichen synusia instead of moss or vascular plant cover (Fałtynowicz 1986). For the conservation purposes attention should also be paid to the Cladonio-Pinetum patches derived from natural succession. They can be dominated not only by pine, but also by birch (Cieśliński 1979; Zaniewski et al. 2012). These patches are mainly considered as Natura 2000 habitat (Interpretation Manual ... 2007). The appropriate development of Cladonio-Pinetum patches in the study site is confirmed by the presence of many characteristic lichen species (for example Cladonia arbuscula, Cl. furcata, Cl. gracilis). Large population of Cladonia stellaris, which is considered to be an indicator of optimal development of the abovementioned community (Zielińska 1967; Cieśliński 1979) is additional evidence for a high quality of the patches. The vitality of the local population is good in spite of the fact, that Cladonia stellaris is endangered (EN) in Poland (Cieśliński et al. 2006).

The studied lichen-rich pine forest stand should be considered as maintained by human activity, which means that it is semi-natural. The naturalness of the Cladionio-Pinetum has aroused many doubts since a long time (Juraszek 1927). Kobendza (1930) and Sokołowski (1980) believed that all phytocenoses of the abovementioned community are degraded by human impact patches of more fertile forests. However Zielińska (1967) drew attention to the stability of many stands of Cladonio-Pinetum. Fałtynowicz (1986) believed, that due to the human impact on forests lasting for centuries the natural and seminatural patches of lichen-rich pine forests are often indistinguishable. Solon (2007) noted, that some old nearly-natural pine forests reaching the disintegration phases in Kampinos National Park are the rich in terrestrial lichens. That finding may implicate that the appropriate microhabitats for epigeic lichens in lowland Central Europe are able to emerge in the pine forest of natural character.

The study area is similar to the lichen-rich pine forest near Kodeń (Eastern Poland) by having specific land ownership structure (small private plots) and being located in a small distance from human settlements (Wójciak \& Urban 2012). Very different ownership and management patterns predominate in the "Bór Chrobotkowy im. Prof. Zygmunta Tobolewskiego" Nature Reserve, located within "Bory Tucholskie" forest complex where the lichen-rich pine forest stands were formerly managed by state forestry
(Lipnicki 2012). The lichen-rich pine forests of "Mierkowskie Suche Bory" Nature Reserve, located in "Bory Lubuskie" forest complex were until recently also managed by State Forests. Similarly to the study area patches of Cladonio-Pinetum within the abovementioned object were connected with dune ridges (Lipnicki \& Grochowski 2012). However within the presented study lichen-rich pine forest was found also on the tops of the dunes not only on the slopes, as in the case of "Mierkowskie Suche Bory" (Lipnicki \& Grochowski 2012). Described Cladonio-Pinetum stand in the vicinity of Stójka village stands out from the rest of abovementioned objects by still present traditional land use, which is so far poorly recognized and understood (Danielewicz \& Pawlaczyk 2004).

\section{Conclusions}

The studied path of lichen-rich pine forest, which is located on dune near Stójka village, has a seminatural $\approx$ anthropogenic character. The most important for its persistence are: - continuity of forest communities as well as anthropogenic disturbance related to selection cutting management,

- low density of forest canopy caused by selection cutting,

- organic and the top mineral soil horizons disturbance connected with tree felling and transport of timber, resulting in a decreased organic horizon thickness or lack of litterfall accumulation,

The result of the study can also help in the effective conservation and management of lichen-rich pine forest, being a Natura 2000 habitat (code 91T0). In order to preserve the patches of the community we propose:

- total cessation of clearcuts in favour of the selection cutting,

- removal of the whole wood after possible thinnings,

- introduction of litter and moss raking and its removal beyond the Cladonio-Pinetum patches.

\section{Acknowledgements}

We are extremely indebted to the anonymous reviewers for their valuable comments and suggestions that significantly helped to improve the manuscript.

\section{References}

Barkmann J. J., Doing H. \& Segal S., 1964, Kritische Bemerkungenund Vorschläge zur quantitativen Vegetationsanalyse, Acta Botanica Neerlandica 13: 394-419. 
Braun-Blanquet J., 1928, Pflanzensoziologie. Grundzüge der Vegetationskunde, Biologische Studienbücher 7, Springer, Berlin.

Celiński F., Wika S. \& Parusel J. B., 1997, Czerwona lista zbiorowisk roślinnych Górnego Śląska [Red list of Upper Silesian plant communities], Raporty, Opinie 2: 38-68.

Cieśliński S., 1979, Udział oraz rola diagnostyczna porostów naziemnych w zbiorowiskach roślin naczyniowych Wyżyny Kielecko-Sandomierskiej i jej pobrzeży [Participation and diagnostic role of the terricolous lichens in the vascular-plant communities in the Kielecko-Sandomierska Upland and its periphery], WSP, Kielce.

Cieśliński S., Czyżewska K. \& Fabiszewski J., 2006, Red list of the lichens in Poland, [in:] Z. Mirek, K. Zarzycki, W. Wojewoda, Z. Szeląg (eds), Red list of plant and fungi in Poland, Kraków: 73-89.

Council Directive 92/43/EEC of 21 May 1992 on the conservation of natural habitats and of wild fauna and flora (OJ L 206, 22.7.1992).

Danielewicz W. \& Pawlaczyk P., 2004, Śródlądowy bór chrobotkowy [Inland Cladonia-Scots pine forest], [in:] J. Herbich (ed.), Poradniki ochrony siedlisk i gatunków Natura 2000 - podręcznik metodyczny, Tom 5, Lasy i bory, [Guide books to protection of Natura 2000 habitats and species - methodical manual, Part 5, Deciduous and coniferous forests], Warszawa: 289-296.

Dingová Košuthová A., Svitková I., Pišǔt I., Senko D. \& Valachovič M., 2013, The impact of forest management on changes in composition of terricolous lichens in dry acidophilous Scots pine forests, The Lichenologis 45 (3): 413-425.

Dzwonko Z. \& Gawroński S., 2002, Effect of litter removal on species richness and acidification of a mixed oakpine woodland, Biological Conservation 106: 389-398.

Faliński J. B., 1990, Kartografia geobotaniczna, Cz. 2: Kartografia fitosocjologiczna, [Geobotanical cartography, Part 2, Phytosociological Cartography], PPWK, Warszawa-Wrocław.

Faliński J. B., Cieśliński S. \& Czyżewska K., 1993, Dynamic-floristic atlas of Jelonka reserve and adjacent areas. Distribution of vascular plant species, bryophytes and lichens on the abandoned farmlands during secondary succession, Phytocenosis 5 (N.S.), Supplementum Cartographiae Geobotanicae 3, Warszawa-Białowieża.

Fałtynowicz W., 1986, The dynamics and role of lichens in a managed Cladonia-Scotch pine forest (Cladonio-Pinetum), Monographiae Botanicae 69: 1-96.

Interpretation Manual of European Union Habitats, 2007, European Commission, DG Environment, Nature and Biodiversity.

Juraszek H., 1927, Pflanzensoziologische Studien über die Dünen bei Warschau, Extrait du Bulletin de I'Académie
Polonaise des Sciences et des Letters, Cl. Sci. Math. Nat., Sér. B, Kraków: 515-610.

Karte Des Westlichen Rußlands, 1915, L28 Goniądz, Skala 1:100 000, Königlich Preußische Landesaufnahme.

Kelly D. L. \& Connolly A., 2000, A review of the plant communities associated with Scots pine (Pinus sylvestris L.) in Europe, and evaluation of putative indicator/ specialis species, Investigacion Agraria, Sistemas Recursos Forestales 1: 15-39.

Kobendza R., 1930, Stosunki fitosocjologiczne Puszczy Kampinoskiej [Phytosociological relations of Kampinos Forest], Planta Polonica 2: 1-200.

Kondracki J., 2009, Geografia regionalna Polski [Regional Geography of Poland], Wydawnictwo Naukowe PWN, Warszawa, Wydanie trzecie, uzupełnione.

Kreutzer K., 1979, Ökologische Fragen zur Vollbaumernte, Forstwissenschaftliches Centralblatt 98: 298-308.

Lipnicki L., 2012, Practical protection of lichens in Poland - experience from the years 1992-2012, [in:] L. Lipnicki (ed.) Lichen protection - Protected lichen species, Sonar Literacki, Gorzów Wlkp.: 43-52.

Lipnicki L. \& Grochowski P., 2012, The lichens of „Mierkowskie Suche Bory" nature reserve, [in:] L. Lipnicki (ed.), Lichen protection - Protected lichen species, Sonar Literacki, Gorzów Wlkp.: 151-161.

Magnuski K., 1997, Urządzanie lasu w Polsce po drugiej wojnie światowej (część 2) [Forest Surveys in Poland in the Period after Second World War], Sylwan CXLI(10): 35-49.

Mapa taktyczna Polski Arkusz P35 S45 Goniądz, skala 1:100000 [Tactical Map of Poland Sheet P35 S45, scale 100000], 1930, Wojskowy Instytut Geograficzny, Warszawa.

Matuszkiewicz J. M., 2005, Przewodnik do oznaczania zbiorowisk roślinnych Polski [A guide for identification of plant communities in Poland], Wydawnictwo Naukowe PWN, Warszawa.

Matuszkiewicz J. M., 2008, Zespoły leśne Polski [Forest associations of Poland], Wydawnictwo Naukowe PWN, Warszawa.

Nordén B. \& Appelqvist T., 2001, Conceptual problems of Ecological Continuity and its bioindicators, Biodiversity and Conservation 10: 779-791.

Prietzel J. \& Kaiser K. O., 2005, De-eutrophication of a nitrogen-saturated Scots pine forest by prescribed litter-raking, Journal of Plant Nutrition and Soil Science 168: 461-471.

Prieditis N., 2002, Evaluation frameworks and conservation system of Latvian forests, Biodiversity and Conservation 11: 1361-1375.

Reymann G. F., 1865, Topographisher Special Karte, Central Europa, Goniądz, 1:200000, Glogau. 
Sokołowski A., 1980, Zbiorowiska leśne północno-wschodniej Polski [Forest communities of North-Eastern Poland], Monographiae Botanicae 60: 1-205.

Solon J., 2003, Scots pine forests of the Vaccinio-Piceetea class in Europe: Forest sites studied, Polish Journal of Ecology 51: 421-439.

Solon J., 2007, Przemiany zbiorowisk leśnych Kampinoskiego Parku Narodowego w ciągu 80 lat [Changes in forest communities of Kampinos National Park during 80 years], [in:] J. M. Matuszkiewicz, J. Solon, M. Orzechowski, A. Kozłowska, W. Różański, M. Szczygielski, G. Matejczuk, B. Lorens, A. Kowalska (eds.) Geobotaniczne rozpoznanie tendencji rozwojowych zbiorowisk leśnych w wybranych regionach Polski [Geobotanical classification of the development tendencies in forest associations in the regions of Poland], Polska Akademia Nauk, Warszawa: 290-342.

Suwała M., 2004, Uszkodzenia gleby w drzewostanach sosnowych przy pozyskiwaniu drewna w praktyce leśnej [The soil damages in pine stands during wood harvesting in forest practice], Leśne Prace Badawcze 1: 87-101.

Tüxen R. \& Ellenberg H., 1937, Der systematische und der ökologische Gruppenwert, Ein Beitrag zur Begriffsbildung und Methodik der Pflanzensoziologie, Mitteilungen der Floristisch-soziologischen Arbeitsgemeinschaft 3: $171-184$.

Van Tol G., Dobben H. F., Schmidt P. \& Klap J. M., 1998, Biodiversity of Dutch forest ecosystems as affected by receiving groundwater levels and atmospheric deposition, Biodiversity and Conservation 7: 221-228.
Węgrzyn M. \& Masłowska M., 2010, 91T0 Śródlądowy bór chrobotkowy [91T0 Inland Cladonia-Scots pine forest], [in:] W. Mróz (ed.), Monitoring siedlisk przyrodniczych, Przewodnik metodyczny, Część pierwsza, [Monitoring of natural habitats, Methodical guide, Part One], Inspekcja Ochrony Środowiska, Biblioteka Monitoringu Środowiska, Warszawa: 295-311.

Wójciak H. \& Urban D., 2012, Cladonio-Pinetum forests near Kodeń - their natural values and need for protection, [in:] L. Lipnicki (ed.) Lichen protection - Protected lichen species, Sonar Literacki, Gorzów Wlkp.: 163-172.

Zaniewski P., Dingová A., Valachovič B. \& Wierzbicka M., 2012, The conservation status of Cladonio-Pinetum Juraszek 1927 in Mazowiecki Landscape Park and adjacent areas (Poland), [in:] L. Lipnicki (ed.), Lichen protection - Protected lichen species, Sonar Literacki, Gorzów Wlkp.: 173-185.

Zerbe S., 2002, Restoration of natural broad-leaved woodland in Central Europe on sites with coniferous forest plantations, Forest Ecology and Management 167: 27-42.

Zielińska J., 1967, Porosty Puszczy Kampinoskiej [Lichens of the Kampinos Forest], Monographiae Botanicae 24: 1-130. 